\title{
Educational Status of the Hill Kharias of Mayurbhanj District of Odisha in East India : A Psychological Analysis
}

\author{
Fagu Tudu ${ }^{1}$ And Ratnakar Mohapatra ${ }^{2}$ \\ RGNF Ph. D. Research Scholar, Department of History, KIIT, Deemed to be University, Bhubaneswar, Odisha, India \\ Email.ID- tudufagu88@gmail.com \\ Assistant Professor, Department of History, KISS, Deemed to be University, Bhubaneswar, Odisha, India \\ Email.ID-ratnakarmohapatra2017@gmail.com
}

\begin{abstract}
:
Education in tribal societies has helped in maintenance of social structure and goal attainment for a sustained living. The Hill Kharias are the primitive tribal people of Mayurbhanj of the state of Odisha in Eastern India. The development of education of the Hill Kharia community/society of Mayurbhanj is the main aspect of the improvement of the primitive tribal communities of the state of Odisha. The Government of India issued directions vide the letter. No. 20018 5/81- ITDA dated 27th April 1980 for the identification of Primitive Tribal Groups, keeping in view the facts that attention to certain tribal groups' backwardness. In India Hill Kharia is one of the primitive tribal groups living mainly in the forest and hilly covered areas of the Mayurbhanj district of Odisha. Mentally, the people of Hill Kharia tribe of Mayurbhanj are very weak, because of lack of proper education, awareness, adequate foodstuffs, for which they are backward in present society. Odisha has possessed a distinct place in tribal history of India and it is the home of a number of different types of tribes. Different development programmes for education have been implemented through the different govt. or Non govt. agencies. On the basis of field study made by the earlier scholars including the present authors, the Hill Kharias are residing in the Mayurbhanj district of Odisha. The aim of this paper is to focus on educational status of the Hill Kharias of Mayurbhanj district of Odisha. Methodologically, both the primary and secondary sources have been used in the present article.
\end{abstract}

Keywords: Education, status, Primitive, Hill Kharia, Tribe, Mayurbhanj, Odisha, India.

Article Received: 18 October 2020, Revised: 3 November 2020, Accepted: 24 December 2020

\section{I.INTRODCTION}

Education is the basic input for socioeconomic development of an individual and a key factor for determining the national progress. Generally, the traditional educational system was mostly the worldview of the tribal people. Modern education is being imposed on the tribal, which most often does not refer to the tribal culture to which they are acquainted with since generation is not properly accepted by them and thus in many cases, tribal take it negatively (ADIVASI, Volume-50, June\& December,2010, p.131). Socially and educationally the Scheduled Tribes (ST's) are among the most disadvantaged groups in Odisha. In fact, Odisha was an educationally backward state of India till the advent of the planning in 1950-1951 AD. The level of literacy is low among weaker section of Indian society especially among the tribals. As per the 2001 Indian Census, the populace of the tribal communities of India is $8.27 \%$ of the total people. In India, there are as many as 689 Scheduled Tribes speaking in 105 languages along with 225 speaking supplementary languages (Mohanta, 2015 , p.18). Odisha is regarded as the homeland of a number of different types of tribes. On the basis of field study made by the earlier scholars and the present principal author, the Hill Kharias are chiefly residing in the Mayurbhanj district of Odisha. Hill Kharia was a Primitive Tribal Group of Mayurbhanj district of Odisha in Eastern India. Odisha is aptly considered as the land of a number of different types of Scheduled Tribes numbering sixty two. Among the total sixty two tribes, there are 13 Particularly Vulnerable Tribal Groups (PVTGs) inhabited in the state of Odisha ( Samal, 2001, p.6). Hill Kharia tribe is one of the 13 Particularly Vulnerable Tribal Groups (PVTGs) of Odishain Eastern India, According to 2001 statistics, the total population of Hill Kharia tribe 
was 1673 and it increased to 1908. The Hill Kharias to a great extent depended upon hunting and nourishment assembling. The people of Hill Kharia tribe have the pre-rural degree of innovation and for the most part they are preliterate. Accordingly, in the formative activities, the Hill Kharias of Mayurbhanj have been treated such as a different get-together and named by way of a crude inborn gathering. Hence, they have been improved such as especially powerless innate gathering of India in South Asia (Survey Report, 2001. Hill Kharia \& Mankidia Development Agency, Jashipur, p.12). Mayurbhanj is surrounded on the north by the Singbhum district of Jharkhand and Mindnapur district of West Bengal, on the South by the district of Balasore district and Keonjhar district, in the east by the Mindnapur and Balasore district, on the west by the district of Keonjhar and Singhbhum district, It was the largest and wealthiest of the feud and wealthiest of the feudatory state of Odisah in Eastern India.

The district of Mayurbhanj of Odisha lies between $21^{\circ} 17^{\prime}$ and $22^{\circ} 3^{\prime}$ ' north latitude and between $85^{\circ} 40^{\prime}$ and $87^{\circ} 10^{\prime}$ 'east longitude (Senapati and Sahu, 1967, p.2). In fact, Mayurbhanja is a tribal dominated district of Odisha and as many as 45 Scheduled Tribes including Hill Kharias are inhabiting in this district as per 1961 Census. At present 55 Scheduled tribes are noticed in the district of Mayurbhanj (Tribes in Odisha, 2015). In $7^{\text {th }}$ Five year plan, the Hill Kharia tribe was identified as Primitive Tribal Groups of Odisha and this tribe also included in 1985-90 year for their development. The Hill Kharia \& Mankirdia Development Agency (The Micro Project) was established at Jashipur in the $7^{\text {th }}$ Five Year Plan 1985-90. This agency is covering all the HillKharia \& Mankirdia villages of the Jashipur and Karanjia Blocks of Mayurbhanj district in northern Odisha. In fact, the people of Hill Kharia tribe have a distinct cultural trait of their own. Now, it is found from the observation that their life style is slightly changed due to the introduction of various schemes by the Central and State Governments for development of their education. Initially, the Hill Kharias parents were not interested in education for the future of their children. Subsequently, they are convinced by awareness programmes for educating their children. So it is an interesting study for scholars to know the educational system of the Hill Kharias of Mayurbhanj district of Odisha. The present article attempts to focus on the educational status of the Hill Kharia community / society of the Mayurbhanj district of Odisha in Eastern India. It also highlights the various schemes introduced by the Governments for the educational upliftment of Hill Kharia children of Mayusrbhanj.

\section{METHODOLOGY}

The data collected from both the primary and secondary sources are critically analysed and used in the writing of the article. The primary data have been collected from Gazetteers, folk lore, folk tale, and unpublished thesis, the practical observation, public opinions, hearsay accounts through the interview methods during the period of experimental field survey by the principal author. The field study, personal interview, schedules and taking photographs are made by the present authors. The general field survey has been undertaken for the collection of data relating to the educational status of the Hill Kharias of Mayurbhanj district of Northern Odisha in India. The secondary data relating to the present article are Books, Magazines, Reviews, Journals, Periodicals, Proceedings, Records, Reports, and published and un published theses.

\section{DISCUSSION AND RESULT ANALYSIS}

Importance of education in India has been realized since time immemorial, particularly in vedic period. It is found that in mediaeval period tolls were established by the Brahmin for learning on the sacred aspect, philosophy, literature and science by Brahmin teachers. Another institutions like pathsala was for giving the elementary 
knowledge to the lower caste community members (Mohanta,2015, p.22). During the British period, the government took initiatives in educational department of India. Therefore, Sanskrit schools and Madarasa were opened in few areas for producing court officials (Mohanta, 2015, p.22). Then introduced the English education in $1835 \mathrm{AD}$ by advice of Lord Macaulay. At that time primary education was not compulsory. It was controlled by local bodies and neglected the tribal people in education (Mohanta, 2015 , p.22). Therefore education of tribal was neglected before independence. The earliest efforts for tribal education were made by the foreign missionaries. Hunter commission report(1882) started that efforts of tribal education seems to be credible as most of the Christian tribes show very high literacy rate e.g. the mizos of Mizoram. In this report he also recommended for expansion of the primary education, during the pre-independence period British ruler adopted a strategy of seclusion and maintained status quo of tribes, on the whole to follow the policy of laissez fair (Mohanta, 2015, p.23). Initial efforts by the Indian were started around 1940. Similar efforts were made by some of the Indian voluntary organizations. The Government of India has made certain constitutional provision for the tribals. The article 45 is provided for free and compulsory education for children. Never the less, the article 46 is highly significant to the scheduled tribes as well as other poor sections of India (Mohanta, 2015, p.23). For spreading education among the scheduled castes and scheduled tribes, a number of schemes of incentives have been started by central and states governments. These are free education, scholarship, residential / hostel facilities, Ashram schools, free books and stationary reservation of seats in learning institution in proportion to their population (Mohanta, 2015, p.24).

The Indian Education Commission Report (1964-66), which is commonly referred to as the Kothari Commission Report. Its Chairman D.S. Kothary has stated that "it is necessary to pay special attention to the education of the children from the backward classes, the scheduled tribes, de-notified communities and a few nomadic and semi-nomadic groups"(Shastry, 2010, p.13). The Commission on Scheduled Areas and Scheduled Tribes had critically examined the various facets of tribal education and had provided certain cogent suggestions. The Kothari Commission endorsed the Dhebar Commission approach. The enrolment of Tribal children was much lower in Odisha. On the basis of Kothari Commission, the Tribal Girl's education was emphasized as she was at the rock of bottom of the educational spectrum (Shastry, 2010, p.14). The school calendar should be turned into to the tribal lifestyle. The development of secondary education was a major concern. The Ashram School system is found to be established by the Government of Odisha for developing education among the tribal children. The educational status of the Hill Kharias of Mayurbhanj is briefly discussed below.

\section{Hill Kharias of Mayurbhanj}

Before discussing the educational status of the Hill Kharias, at first we have to know their habitation areas. The Hill Kharias have their stronghold in the wildest parts in the Similipal hill range of Mayurbhanj Dsitrict, Odisha, and have spread further to the north in the hills of the Singbhum (Dhal-bhum Pargana) and Manbhum District of Chotanagpur scattered offshoots of this branch of the Hill Karias have strayed further to the east and north east into the adorning areas of the Midnapore and Bankura Districts of Bengal and south and south-west into the adjoining Odisha state feudatory state of Nilgiri on the south, and Mayurbhanj, Keojhar, Banai, Palhahara and Dhenkanal on the west and Southwest. Of the hill ranges which afford shelter to the Hill Kharias the Similipal range in Mayurbhanj rises to an elevation of from 2,013 to 3,823 feet. On the tops and slopes and at the feet of these Similipal hills and also on and about some smaller hill ranges of the Similipal Hill ranges. The Hill Kharias lead a hand-to-mouth existence by 
collecting jungle produces, by gathering edible herbs and daily fruits and digging out edible yams and tubers with their primitive digging-sticks and rude hoes called Khantas, and occasionally by hunting deer or some smaller game, Shifting agriculture by the wasteful process variously known as Dahi or Koman or Jhum, which they used to practise up till recently is no webbing mostly stopped by the state authorities in Mayurbhanj and a few other states and by the Zamindars in Britishi District. Some Hill Kharias families have recently been induced to come down from the hills and take to plough cultivation. And the climate in Mayurbhanj is more or less humid but in the state of feudatory states inhabited by the Hill Kharias it is dry. In Summer the heat in the lower levels is fairly intense, the temperature sometimes rising as high as $110^{\prime}$ or more but in the higher ranges are fairly cold an invigorating on these hills. But the hill-tracts are more or less melodious, particularly in the rainy season and in autumn and in the earlier part of the cold weather.

In fact, the maximum dropout of children is found among the PTGs / PVTGs owing to their social. economic, cultural and ecological factors (Maharana and Nayak, 2017, p.500). In India 75 Particular Vulnerable Tribal Groups (PVTGs) inhabit in various geographical regions and out of these 13 Particular Vulnerable Tribal Groups (PVTGs) reside in Odisha. Especially, Mayurbhanj is a tribal dominated district where 53 tribes and 4 Particular Vulnerable Tribal Groups are inhabited. Out of these, Hill Kharias is one of the major PVTGs in Mayurbhanj district of Odisha. They are semi-migrant tribe and their sustainability completely relies on forest. Now-adays as they are not additionally getting timberland assets as they were getting prior. Still their monetary condition is poor right now. The empirical study has been done by the principal scholar / authors to focus on the educational system of the Hill Kharias of Mayurbhanj. Prior to the discussion of the educational status / system of the Hill Kharias, we have to know their languages used. The Hill Kharias individuals were/are communicating in their own Kharia language. The Hill Kharias chitchat with one another in different dialects and like Odia, Santali, Munda, Hindi, Ho and neighbor other tribals' language when they chatted with pariah they utilized different sorts of languages ( Dash,1999, p.11 ). Mayurbhanj Hill Kharias individuals for the most part communicating in possess language and Odia language and furthermore neiboughring innate dialects and so on ( Tudu, and Mohapatra, 2020, Vol. No. 7, Issue-7, p. 850).

\section{Education of the Hill Kharias of Mayurbhanj}

Education is the weapon to change the society. Education not just aides in working up person's character, character and insight yet in addition his beneficial limit and his capacity to play out a lot of work all the more productively ( Tudu, and Mohapatra, 2020, Vol. No. 7, Issue-7, p. 851). It additionally uncovers that in essential training the brews rate is higher than the females. This is on the grounds that, with the constrained asset they like to instruct just for their male kids. The Hill Kharias individuals rely upon the Government run instruction organization, They don't have legitimate garments to wear and furthermore incapable to hold up under the expense of school uniform, scratch pad, pen and pencils additionally authorizes many younger students' to drop tightening advanced education ( Tudu, and Mohapatra, 2020, Vol. No. 7, Issue-7, p. 851). Be that as it may, presently however the Government is without giving school outfits yet guardians can't bear the cost of other consumption once in a while charged by the School. Due to some reasons number of understudies drops out even at the essential level from instruction. In addition, after the beginning of adolescence, the customary and moderate guardians like to hold their little girls at home and organize marriage as opposed to sending them to class. Many Hill Kharias young ladies don't want go for advanced education since they study advanced learning educational plan is troublesome so this is smarter to remain at home to help family unit works ( 
Tudu, and Mohapatra, 2020, Vol. No. 7,Issue7,p.851). Now-a-days Government of Odisha has taken so many developmental programmes for advancement of training among the Hill Kharias through Hill Kharias and Mankidia Development Agency office, Jashipur ( Bhowmick, 2013.,pp. 83-85).The School provides everything to the Hill Kharia children like dresses and other materials for their education. Now, the Hill Kharias are attentive to offernew education to their children. At present the Hill Khariasgirls are going to school for education and the boys also wanted to be more educated in that community (Tudu, and Mohapatra, 2020, Vol. No.7, Issue-7, p. 851). Because, the educated Hill Kharia girls and boys can get high status in their society. In some areas Anganbadi Centre are found to be provided with min-day meal for the below 5 years children (Banerjee,1982. p.69).

\section{Educational Development of Hill Kharias of Mayurbhanj}

The traditional institutions of education of tribals, particularly vulnerable tribal societies were of different kinds. Formal schools entered late in the tribal societies of India. The Constitution of India contains educational safeguards for Scheduled tribes. The schools were established to bring about changes in the life of the tribal people so that they could fit themselves into the modern society (ADIVASI, Volume-50, June \& December, 2010, p.3) . The form and nature of education the subject of study the stud at teacher relationship and above all the role of the state and individuals in promoting the education. The work reveals that the educational system was based upon ancient theory of knowledge. Its special aim was to make a man efficient to attain salvation. Which were the basic needs of life one could attain all the above said objects only through the liquidation of three rains and performance of Hill Kharia tribe. Since our epigraphic records do not lay sown any direct reference to three fiats and the present scholar have tried to trace it out from the character eulogy of some eminent scholar and other personalities.

All societies depend primarily upon the socialization of their members, this, again, involves the conditioning of a society's members so that they absorb the norms, the knowledge, and the habits requisite to their acceptable adjustments within society. In the all societies development education coordination is to train its undeveloped generations of the tribal people (Tudu, and Mohapatra, 2020, Vol. No. 24, Issue-2, p.7213). The society's develop educational systems to train to its technology are transmitted through it. The young must be deliberately skilled for their mature rules to uphold the social order. The individual possesses no knowledge or understanding of values, standards or rules of his society at birth he must be taught them, Individuals themselves cannot easily survivor if they do not learn the way of adopting to the environment. They must be socialized, they must consciously and unconsciously adopt the ways of their societies. They must necessarily learn the ways of producing food, clothing, shelter or avoiding danger and illness, and of adjusting to the groups about them. There are no other ways to acquire them. Youth cannot learn well if they were left to chance. Every society, assumes that it will function more effectively if its members learn the techniques and the ideals and values that are essential for their welfare. Hence the Hill Kharia young must be presented into the culture, which he is working in their Society(Tudu, and Mohapatra, 2020, Vol. No. 24, Issue-2, p.7213). Education delivers sensible teaching programmes that help to teach values, customs and social skills will enable the specific to develop normally and to withstand the social system. Education is thus broadly speaking the social process by which, one person learns the things essential to fit him for the life cycle of his society (Senapati and Sahu, eds. ,1967,pp.363-364).

After independence several steps and educational schemes were taken up by the Union and State Governments for promoting education 
among the people especially the weaker sections like Scheduled Tribes. Gradually, the educational development programmes were broadened and more schemed are found to be introduced in tribal areas of India. Although Hill Kharias villages have been accessed to accumulate statistics for their study, but the State government has supported the Hill Kharias and Mankidia Development Agency (HK\&MDA). It seems in the end of fundamental troubles associated with the both Hill Kharia and Mankadia tribes (Tudu, and Mohapatra, 2020, Vol. No. 24, Issue-2, p.7214). The Hill Kharia villages under HKMDA micro-project advanced get right of entry to statesupporter interventions, specially schooling. However, in the literacy price a few of the tribes is still miserable. They trust with inside the conventional machine of schooling that is informal, useful, as well as need-based (Tudu, and Mohapatra, 2020, Vol. No. 24, Issue-2, p.7214). It allows them to hold harmony and loyalty to their own traditional customs. Hence, only some have well-known the shape college machine. Most youngsters attend instructions most effective for the mid-day meal as well as their stimulus in the direction of research may be very poor(Tudu, and Mohapatra, 2020, Vol. No. 24, Issue-2, p.7214). Many far flung faculties have few lady instructors and absenteeism makes the state of affairs worse. Furthermore, the networks of individuals keep distance from different individuals of the network. For instance, if a lady or boy of Hill Kharia's own circle of relatives is going to college, the neighbor distinguish and separate them, which disapproval approximately schooling and consequences in dropout (Tudu, and Mohapatra, 2020, Vol. No. 24, Issue-2, p.7214).. This is not unusual place hassle amongst Hill Kharis tribe is that mother and father have interaction youngsters in accumulating woodland product. And their lady not often visits their faculties schooling, and toddler marriage is rampant (Tudu, and Mohapatra, 2020, Vol. No. 24, Issue-2, p.7214). Some households have been found to have transformed to Christianity, which performs a chief position of their college schooling (Tudu, and Mohapatra, 2020, Vol. No. 24, Issue-2, p.7214). These households are greater prompted to ship their ward to faculties, each state-supported faculties, and missionary school (Samal, 2001, pp. pp.118-122). (Ram Chandra Dehuri, Padagada village, $10^{\text {th }}$ passed as a work teacher in Education complex at Angarpada), Siba Dehuri, +2 ct. working as Teacher at Angarpada educational complex, Barua Dehuri, village Padagarh village, B.A passed working big Contractor in their area or G.P., Kalipada Bhakta, Dhenkinejia village, Godia G.P, Baripada Suliapada block, +3 passed in 2000, Cultivator and Contractor, he cultivate Sabai Grass, in 3 acre, Bijay Dehuri, 21 year Gurgudia,Jahsipur block, studying in Raruan Collage in $+31^{\text {st }}$ years (Tudu, and Mohapatra, 2020, Vol. No. 24, Issue-2, p.7214).

Under the scheme of Integrated Child Development Services (I.C.D.S.), government has also opened Anganwadi in Hill Kharias villages in Mayurbhanj district(Tudu, and Mohapatra, 2020, Vol. No. 24, Issue-2, p.7214). The government has appointed one Teacher and is helper. One supervisor has been appointed by the government to look after the Anganawadi, which come under I.C.D.S. Programmes. How to they will get help / opportunity for anything like health hygiene and pregnancy treatment or delivery. Everything are trying to provide for the Hill Kharias people by the HK \&MDA or ICDS, or Govt. of Odisha ( Bhowmic, 2013, pp.84-90).

\section{Hill Kharia Children in the Educational Complex}

The tribal welfare Department provided some Ashrama/school hostels, but there is no provision for purchase of papers, books and other things meant for the student reading in these schools. Under the modified scheme, its coverage in the country includes as many as 54 recognized Districts of India where the ST people are $25 \%$ or extra and ST females literacy rate is lower than 35\% accordingly the 2001 Census of India (Bhowmick, 2015, p.683). In Odisha state, 
the operation of the Educational Complex Scheme for tribal girls extends to the districts such as Gajapati, Kandhamala, Nuapada, Kalahandi, Koraput, Keonjhar, Mayurbhanj, Balangir as well as the areas of 13 PVTGs in '17' Micro projects (Sahu, 2010, pp. 167-168). On the basis of Educational Complex Scheme for the tribal girls, an Educational Complex for the tribal girls is found to be established at Angarpada Village in the Jashipur Block of the Mayurbhanj District. This Educational Complex is established by the Hill Kharia and Mankadia Development Agency, Jashipur. In which the tribal Hill Kharia girls are being taught by the Government with free of cost. This Educational Complex of Angarpada Village in the Jashipur Block is providing hostel facilities to the tribal girls particularly for Hill Kharia and Mankidia families /community. This scheme will promote $100 \%$ enrolment of scheduled tribe girls of primitive tribal groups of Odisha.

In the past it was a dream for the HillKharias and Mankirdia children to access education. The Hill-Kharia and Mankindia PVTGs both tribes primarily reside in the hill slopes of Similipal forest region. There were no residential schools for the PVTGs, so the children of these Communities were deprived of the education and the literacy rate was very low varying from $0 \%$ to $15 \%$ (Tudu, and Mohapatra, 2020, Vol. No. 24, Issue-2, p.7214). Since they were living in inaccessible areas there was no interest among these Communities for education. Govt. in ST \& SC Development Department gave Special emphasis to bring those children to the Educational Institutions, in the $11^{\text {th }}$ plan period under CCD Plan (Tudu, and Mohapatra, 2020, Vol. No. 24, Issue-2, p.7214). Accordingly one Girls Education Complex was established at Angarpada Village in Jashipur Block under Hill Kharia and Mankindia Development Agency (HKMDA), Jashipur with Support from MoTA, Govt. of India and ST \& SC Development
Department, Odisha (Tudu, and Mohapatra, 2020, Vol. No. 24, Issue-2, p.7215). In the Year 2007 2008, all the teaching and non-teaching Staff of the Education Complex were selected from among the PVTGs Communities(Tudu, and Mohapatra, 2020, Vol. No. 24, Issue-2, p.7215). This complex in addition to the formal education is also imparting the vocational and life skill education to the students. The complex is residential and now as many as 370 Hill-Kharia and Mankindia Girls are residing in the hostel complex and continuing their studies (Tudu, and Mohapatra, 2020, Vol. No. 24, Issue-2, p.7215). Govt. ST \&SC Development Department, Odisha have been pleased to upgrade the Educational Complex Class I to Class X during the year 2014-2015 and a total of 30 Hill Kharias and Makidia Girls are going to appear in the Annual HSC Exam 2016 (https:doi.org/10). The multi purpose workers and some general teachers and some Hill Kharias people also working in the Micro project are playing a key role in bringing the PVTGs children in to the Educational Complex. Keeping the success of the Girls Educational Complex in view, Govt. in ST \& SC Development Department, Odisha has been pleased to establish one Boys' Educational Complex at Angarpada in Jashipur Block of HK\& MDA, Jashipur during the $12^{\text {th }}$ plan period under CCD plan in the year 2014-15 and a total of 100 Hill Kharias and Mankindia boys have been enrolled in Class I to VII and continuing their study and staying in the Hostel (Tudu, and Mohapatra, 2020, Vol. No. 24, Issue2 , p.7215). Now this has been helpful in raising their literacy rate from $14.41 \%$ in 2007 to 31.13 $\%$ in 2015 (Tudu, and Mohapatra, 2020, Vol. No. 24, Issue-2, p.7215). Every things free of cost provided by Govt. of Odisha as well as India, Specially how to develop own their society and how will be change their traditional thought and special economic development (Tudu, and Mohapatra, 2020, Vol. No. 24, Issue-2, p.7215). 
TABLE-1

\begin{tabular}{|c|c|c|c|c|}
\hline \multicolumn{5}{|c|}{$\begin{array}{l}\text { Enrolment status of the Hill Kharia Children in Educational } \\
\text { Complex, Angarpada, Jashipur: 2019-20 }\end{array}$} \\
\hline SLNo. & Class & Girls & Boys & Total \\
\hline 1 & Class-I & 17 & 22 & 39 \\
\hline 2 & Class-II & 15 & 08 & 23 \\
\hline 3 & Class-III & 19 & 13 & 32 \\
\hline 4 & Class-IV & 41 & 20 & 61 \\
\hline 5 & Class-V & 25 & 22 & 47 \\
\hline 6 & Class-VI & 42 & ----- & 42 \\
\hline 7 & Class-VII & 32 & ----- & 32 \\
\hline 8 & Class-VIII & 27 & ----- & 27 \\
\hline 9 & Class-IX & 19 & ----- & 19 \\
\hline 10 & Class-X & 25 & ----- & 25 \\
\hline & Total & $\mathbf{2 6 2}$ & $\mathbf{8 5}$ & $\mathbf{3 4 7}$ \\
\hline
\end{tabular}

Source: (This status is collected from the office of Educational Complex, Angarpada, Jashipur, Mayurbhanj, Odisha, India)

\section{Other Educational Schemes for Tribal / Hill Kharia Children}

The concept of Tribal Sub-Plan emerged out of the recommendations of the Task force and guidelines were issued by the Planning Commission as well as the Ministry of Home Affairs, New Delhi for preparation of Sub-Plan for tribal regions. The tribal Sub-Plan of Odisha covers the areas of Koraput, Mayurbhanj and Sundargarh districts (TEOCE: A State Paper, 1994, pp.7-8). In the Modified Area Development Approach (MADA) pockets both individual benefits oriented scheme and community profit oriented programmes for welfare of the tribals are under implementation. In addition to the educational development of the tribal people covered under the tribal sub-plan areas. It is felt essential to go for a concurrent exercise so that the inadequacies and short comings of tribal education in the Modified Area Development Approach (MADA) pockets are evolved.

On the basis of central Government's tribal schemes, Integrated Tribal Development Agency ( I.T.D.A) was set up at Baripada and also another I.T.D.A was found to be set up at
Kaptipada Blocks of Mayurbhanj district. National Policy on Education 1986 with modifications was undertaken in 1992. Some of measures were taken in the Hill Kharia areas as well as other tribal zones of Mayurbhanj are viz.1. Primary schools are found established in the different local areas of the Hill Kharia community/ society. 2. School buildings have been built in the different places of Jashipur, Karnjia , Morada, Suliapada, Udala, Badashahi, Khunta, Shama Khunta, Baripada, Thakurmuda, Rsgobindpur, Bangirposhi,, Rairangpur, Kaptipada, etc. Blocks of Mayubhanj district.

Really, so for as the educational scheme of Government of India is concerned different types of schools like Anganwari, Non-formal and Adult education centers are found to be established in the areas predominantly inhabited by the Hill Kharias as well as other tribal communities of Mayurbhanj. Sarva Siksha Abhiyan was launched in India since 2003. It was also implemented in the tribal areas of Odisha. DPEP was the foundation of the SSA and the scheme was initiated in 1994 and the prime objective of this was to provide all children with access to primary 
education within formal system, which was started during 1079-80. The Mid-Day-Meals Scheme was started in the year of 1995. Kasturba Gandhi Balika Vidyalaya (KGBV) is residential upper primary schools for girls students of ST and SC communities. One KGBV has been established at Takatpur in the Baripada Block, and another one at Baliadhia of Morada Block of Mayurbhanj district for SC and ST girls children. Similarly KGBVs have also found to be established in different places of Badasahi, Jashipur, Morada, Rasgovidpur,Suliapada Blocks of Mayurbhanj district. Unfortunately, the Hill Kharia children are not going to read in this Nodal school. National Programme of Education for Girls at Elementary Level (NPEGEL) were also started by the Government of India in tribal areas of Mayurbhanj. The Ministry of Tribal Affairs provide financial assistance to construct different categories of educational institutions in the tribal areas of all states including Odisha. In this way, many changes are found in the tribal children's education system of India. In spite of different attempts made by the Central Government as well as State Government, the literacy rate of Hill Kharia children is very low in comparison to other communities / tribes of Odisha.

\section{Role of KISS for Educational Development of Hill Kharia Children}

In fact, education reforms the process through which students can learn something. It is categorized under Primary or Elementary, Secondary and Higher, Post Higher Secondary. There are various phases attached to the term education take Formal, Non-formal, Vocational, Adult, etc. Indigenous education as somehow similar to the expression we use as tribal education (Mohapatra, 2020, Vol.7, Issue-6, p.330 and Patnaik, 2010, pp.104-105). On the basis of the National Policy on Education (NPE), emphasis has been giving on opening of Primary schools in tribal areas. Despite pragmatic policies of the government, the tribal children have been lagging behind the general children and reasons can be categorized as internal and external (Mohapatra, 2020, Vol.7, Issue-6, p.330 and Patnaik, 2010, pp.104-105). While the inner limitations refer to problems related to school system, contents, medium of instruction, pedagogy, academic supervision and teacher-student relation, the outer limitations are related to difficulties at points of program, planning, application and administration (Patnaik, 2010, pp.104-105). With this backdrop, education to be imparted to the tribal children appears to be stupendous task in Odisha with 62 tribes including 13(thirteen) Primitive Tribal Groups constituting almost $23 \%$ of the total population (Patnaik, 2010, pp.104-105). Really, the tribals of Odisha including Hill Kharias speak as many languages and dialects and it becomes difficult to teach them in their own dialects. In the practical field observation, it can be said that there is need for link language to teach the Hill Kharia children of Odisha.

With the different beneficiary objectives for the tribal children including the children of Hill Kharia community of Mayurbhanj, Kalinga Institute of Social Sciences (KISS), Bhubaneswar initiated with only 125 nos. of Tribal children in the year 1993, has now turned into the largest residential Institute of Asia for the tribal children (Patnaik, 2010, pp.104-105). All the tribal children of Odisha and outside state are being admitted in to different classes for getting education at KISS campus, Bhubaneswar, Odisha. Here all the tribal children including a few Hill Kharia tribe children are provided with education, food, lodging, health care, dress as well asother facilities of life absolutely free. Due to strong determination and dedication for educating the tribal children, now the KISS became the largest residential institute of India exclusively for 27,000 tribal children. Kalinga Institute of Social Sciences has got the status of University on $25^{\text {th }}$ August, 2017. The KISS has become a perfect center of teaching learning for the poor sections of the tribal community having a focus on sustainable livelihood, education and scope for all round development (Patnaik, 2010, p.105). KISS 
is providing different types of education / opportunities for the social and educational development of tribal children. This institute is determined to provide maximum exposure to the tribal children by giving them opportunities to excel in their skills through education, extracurricular training and several vocational training courses, like preparation of saline, tailoring, fishery, handicrafts, etc. KISS serves a dual purpose, because with those activities the children remain connected to nature and the environment while vocational training instills confidence in them (Patnaik, 2010, pp.104-105 and Mohapatra, 2020, Vol.7, Issue-6, p.330). The novel scheme to be paid for their work is like "earning while still learning" makes KISS unique.

The tribal children including Hill Kharias are provided with the facilities to pursue their studies from Kindergarten to Post Graduation ( KG to PG, Ph. D.) level at the Kalinga Institute of Social Sciences since 1993. Although the children of Hill Kharia community at KISS is exceptional still attempts are being made by the team of KISS to motivate the Hill Kharia families for sending their children to KISS, for which the poorest Hill Kharia children of Odisha can come to the main stream of the society like other tribes. Year after year the children, appearing the High School certificate examination are coming with a hundred percent pass result against the state average of 54\% (Patnaik, 2010,p.106). Really, KISS has successfully arrested the problem of dropout without even a single case noticed as yet. The problem of dropout of tribal children including Hill Kharia children are being checked completely. The papers, pens, books and other teaching aids are being provided by KISS to the tribal children, so they do not face any difficulty in getting quality education, students and teacher $\&$ including the present author are staying together in campus (Mohapatra, 2020, Vol.7, Issue-6, p.330). The major objective behind the conceptualization of the KISS is to empower the indigenous children through free holistic and quality education (KISS Annual Report 2015-
2016, p.22). In fact, KISS has many ambitious plans up to its sheaths. In this respect Professor Achyuta Samanta, the Honourable Founder of KISS is of the view that giving education to tribal children is like giving vision to a visuallyimpaired person. It is really an ideal view of a good philanthropist of the world.

\section{CONCLUSION}

We can conclude from the above discussion that the Hill Kharias are the Primitive Tribal people of Mayurbhanj district of Odisha in Eastern India and their educational status is pitiable. The Hill Kharias of Mayurbhanj are backward and they were residing in the remote Hilly/ forest areas. After the Fifth Five year plan period, Government has implemented various plans and policy for the better living condition of Hill Kharias and their development of socioeconomic level. Both the Central and State Governments are providing special provision for the particular vulnerable people like special school for both girls and boys. Governments try to develop how these excluded population will be include in the main stream people and they will live in better conditions with developing their social, economic, education, culture, etc. In the past, Hill Kharias were not interested in education, for which the literacy rate was the lowest in comparison to other tribal communities of Mayurbhanj. On the basis of different Educational schemes of Central and State Governments, Anganwari centres, free residential school like Girls Educational Complex and Boys Educational Complex of Angarpada and established through the Hill Kharia and Mankadia Development Agency, Jashipur. Through the ITDA of Baripada and Kaptipada, LDA, different types of educational schemes of Governments are being introduced for the Hill Kharia children of Mayurbhanj. Now a days, the children of Hill Kharia tribe are interested in modern education, At present primary schools, M.E. Schools and High Schools are found to be established in different places for the Hill Kharia community of 
the Mayurbhanj district. For the spread of education in tribal communities, Kalinga Institute of Social Sciences (KISS) of Bhubaneswar is providing different types of education / opportunities for all the tribal children including the Hill Kharia children of Mayurbhanj. This institute is determined to provide education, extra curricular training and several vocational training courses for the children of all the tribal communities of India. With the establishment of the Educational Complex for Boy's and Girl's of Hill Kharia tribe at Angarpada, for the first time, the regular drop out of Hill Kharia children is checked. In spite of various Government Educational schemes, a few NGOs are also attempting for the spread of education among the Hill Kharia community of Mayurbhanj through the different awareness programmes. A few of the Hill Kharia children are admitted into nearby colleges for higher education. Initially, the parents of Hill Kharia community were reluctant to send their children to nearby schools for their education, but due to awareness programmes made by the Government of India as well as Odisa, the mentality of Hill Kharia people are slightly changed. Similarly, children of the Hill Kharia community are also now interested in modern education. In spite of various steps taken by the Governments and NGOs, the literacy rate of Hill Kharia tribe is very poor in comparison to other tribal communities of Mayurbhanj district of Odisha in Eastern India.

\section{Acknowledgement}

We are extremely grateful to Prof. H.K. Satapathy, Dr. P. K. Routray, Prof. Harihar Panda, Prof. P.K. Nayak, and Prof. Byomakesh Tripathy for their encouragement and valuable suggestions in the course of preparation of this article.

We express our profound reverence to Prof. Achyuta Samanta, the Hon'ble Founder of KISS, Deemed to be University, Bhubaneswar who encouraged us for the writing of this piece of work.
References

[1] Senapati, N. \& Sahu, N. K., eds. (1967). Orissa District Gazetteers Mayarbhanj, Orissa Government Press; Cuttack.

[2] Behura , N. K. (2004). Tribal of Odisha, Schedule Caste and Schedule Tribes Research and Training Institute, Bhubaneswar.

[3] Samal, A.(2001).Tribal Development administration; case study of District in Odisha,ISEC, Nagarbhavi post,Bangalore.

[4] 'Survey Report' (2001). Hill Karia \& Mankidia Development Agency, Jashipur.

[5] Primitive Tribal group of Odisha,(2008).Published by Schedule Caste and Schedule Tribes Research and Training Institute (SCSTRTI), Bhubaneswar.

[6] Tribes in Odisha at a GlanceEmpowering the Tribals of Odisha, (2015). Scheduled Castes \& Scheduled Tribes Research and Training Institute Bhubaneswar, Odisha.

[7] Ota, A.B., Mohanty. S.C. \& Patnaik, K. (2016). Kharia (Photo hand book), SCSTRTI, Bhubaneswar.

[8] Nayak, U.K. (2004). Mayurbhanj Parichaya (Odia book), Royal publication, Baripada, Mayurbhanj.

[9] Vidhyarthi, L.P. \& Upadhyay,V.S. (1980). The Hill Kharia Then and Now: A Comparative Study of Hill, Dhelki and Dudh Kharia of Central Eastern Region of India, Concept Publishing Company New Delhi.

[10] Behera, Bhabatosh, (July-1968). An Economic Condition of the Hill Kharia Tribe (Article of N.O.U.Adivasi(Journal) Vol.-X, Tribal Research Burea Orissa.

[11] Tribes in Odisha at a Glance Empowering the Tribal of Odisah,(2015). Scheduled Castes \& Scheduled Tribes Research and Trainging Institute Bhubaneswar, Odisha.

[12] Ota. A.B. (2009). Pahadi Khadia (Odia), Edited by Adivasi Tribal Language and Cultural office, Bhubaneswar, Odisha. 
[13] Sinha, D. (1984).The Hill Kharia of Purulia Impact of poverty on a Hunting and Gathering Tribe, Published by The Director Anthropological Survery of India Government of India 27 Jawaharla Nehru Road ,Calcutta.

[14] Upadhyay, V.S. (2000). Hill Kharia / Sabar, Jharkhand Tribal Welfare Resarch Institute, Ranchi.

[15] Ota, A.B., \& Sahoo, T. (2009). Hill Kharia (Photo Hand book) SCSTRTI, Bhubaneswar, Odisha.

[16] Roy, S.C., and Roy, R.C. (1937). "THE KHARIAS", in Man in India,Vol. 1, Ranchi.

[17] Ota, A.B., S. C., Mohanty and Patnaik,K. (2016). Kharia, Published by SC \& STRTI C.R. P Square Bhabaneswar, Odisha.

[18] Mohanty, S.C. (January-1982)."Didayi: A Picturesque Tribe of Orissa", in ADIVASI, Edited by Tribal \& Harijan Research-Cum trainings Institute, Government of Orissa Bhubaneswar.

[19] Singh Deb Sachan, J. N. (2012). "SocioEconomic and Cultural Profile of The Kharias of Mayurbhanj", in Proceedings of the Odisha History Congress, Vol. XXXIII Annual Session.

[20] Tudu F., and Mohapatra, R. (February2020). “ CHANGES OF SOCIAL AND CULTURAL LIFE OF HILL KHARIAS OF MAYURBHANJ DISTRICT OF ODISHA IN EAST INDIA", in A.J. Anderson (ed.), International Journal of Psychosocial Rehabilitation, Volume No.24, Issue-02,

Hampstead Psychological

[21] Associates, London; United Kingdom.

[22] Behera, B. (2015). An Educational Status of Hill Kharia of Jhinei Village Samakhunta Block Mayurbhanj District Odisha, A Dissertation report of M.Phil, P.G. Department of. Anthroplogy, North Odisha, University,Baripada, Mayurbhanj.
[23] Dash , J. (1999). Human Ecology of Forager , Commonwealth Publishers Ansari Road, Darya Ganj, New Delhi.

[24] Banerjee, G.C. (1982). Introduction to the Kharia language, Bahri Publications, New Delhi.

[25] Mahrana , R.\& Nayak, J.K. (2017).“Food and Habit and Food Preparation Among the Hill Kharia Tribe of Mayurbhanj District, Odisha, An Anthropological Study", in International Journal of Academic Research and Development, Vol..2, Issue-6 November.

[26] Mohanty, P.K. (2017). Encyclopadia of Primitive Tribes in India, Volume-1, Kalpaz Publication, Delhi.

[27] Bhowmick, P. K. (2013). Primitive Tribal Groups in Eastern India Welfare and Evaluation, Gyan Publishing House, New Delhi.

[28] Bage,M. (1960). Phanomenologie der Munda-Religion, Freie University, Berlin.

[29] Banerjee ,G.C. (1982). Introduction to the Kharia Language, Bahri Publications, New Delhi.

[30] Ota, A. B. \& . Sahoo, A.C. (Compiler), L.Bhol and B. Das (Data Collection), Mahanti,K. K. ed.(2009). Phadia Khadia (Odia Book), Published by Member Secretary Academy of Tribal Languages \& Culture Adivasi Exhibition Ground Unit-1 Bhubaneswar.

[31] Sahoo, L. (May-2011). Kumar, "SocioEconomic profile of Tribal populations in Mayurbhanj and Keonjhar District", in Orissa Review,Cuttack.

[32] Patnaik, S. (2010). "Educating the Tribal Children-The KISS Way", in Ota, A.B. , Bara, F. and Patnaik, K., eds., Dimension of Tribal Education in Odisha, Scheduled Castes and Scheduled Tribes Research and Training Institute, Government of Odisha, Bhubaneswar.

[33] Shastry, V.B. ( 2010). "Tribal Education Policy: Promises and Performances", in 
Ota, A.B., Bara, A.B. and Patnaik, K., eds., Dimension of Tribal Education in Odisha, Scheduled Castes and Scheduled Tribes Research and Training Institute, Government of Odisha, Bhubaneswar.

[34] Tudu, F. and Mohapatra, R. (May-2020). "SOCIAL LIFE OF HILL KHARIAS OF MAYURBHANJ OF ODISHA IN EASTERN INDIA: A HISTORICAL ANALYSIS", in Journal of Critical Reviews, Vol.7, Issue-7, Taiwan.

[35] Mohanta,S. (2015). An Educational Status of Hill Kharias of Jhinei Village, Shamakhunta Block Mayurbhanj, Odisha, A dissertation submitted to the P.G. Department of Anthropology and Tribal Studies, North Orissa University, Sriramchandra Vihar, Takatpur, Baripada, Mayurbhanj, Odisha.

[36] Tribal Education in Odisha in the Context of Education for All by 2000 AD: A State Paper, (1994). Published by Tribal Welfare Department, Government of Odisha, Bhubaneswar.

[37] KISS Annual Report (2015-2016). Kalinga Institute of Social Sciences, Bhubaneswar.

[38] Patnaik, N. (2005). Primitive Tribes of Orissa and Their Development Strategies, D.K. Print World (Pvt.), New Delhi.

[39] Mohapatra, R. (April-2020). "DEVELOPMENT AND CHANGE OF THE PEOPLE OF LODHA TRIBE OF MAYURBHANJ OF ODISHA IN EASTERN INDIA", in Journal of Critical Reviews, Vol 7, Issue 6, Taiwan.

[40] Ota, A.B., ed. (2014). Statistical Hand Book of Tribal Sub Plan (TSP) Blocks in Odisha, Scheduled Castes \& Scheduled Tribes Research and Training Institute, Government of Odisha, CRPF Square; Bhubaneswar.

[41] Nadeem Hasnain, (First Edition: 1991Reprint: 2016). Tribal India, Plaka Prakashana; Delhi.
[42] Ota., A.B. , Mohanty, S.C., T. Sahu, \& Mohanty, B.N. ( 2008). Primitive Tribal Groups of Odisha, Scheduled Castes and Scheduled Tribes Research and Training Institute (SC\& ST RTI), Bhubaneswar.

[43] Sahu, T. (2010). "Educational Complex for ST Girls Students in Low Female Literacy Pockets of Orissa", in Ota, A. B. , Bara , F., and Patnaik, K. eds., Dimensions of Tribal Education in Orissa, SCSTRTI, Bhubaneswar.

[44] Shastry, V.B. ( 2010). "Tribal Education Policy: Promises and Performances", in Ota, A.B., Bara, A.B. and Patnaik, K., eds., Dimension of Tribal Education in Odisha, Scheduled Castes and Scheduled Tribes Research and Training Institute, Government of Odisha, Bhubaneswar.

[45] Tribal Education in Odisha in the Context of Education for All by 2000 AD: A State Paper, (1994). Published by Tribal Welfare Department , Government of Odisha, Bhubaneswar.

[46] Ota, A.B., Mall, A., Das, R.K. and Mohanty, S.C. (June \& December, 2010). "Education For Tribes of Orissa", in ADIVASI, Vol. 50, Issue No.1, Journal of Scheduled Castes and Scheduled Tribes Research and Training Institute, Bhubaneswar. Odisha, India.

[47] Sahu, C. (1998). Primitive Tribes of India. Sarup and Sons Publishers, New Delhi.

[48] Maharana, R. and Nayak, J.K. (2017)."Educational Status of the Particularly Vulnerable Tribal Groups of Odisha", in International Journal of Applied Research, Vol.4 (3), pp.499-504.

[49] Hill Kharia, (2008). Scheduled Castes and Scheduled Tribes Research and Training Institute, SCSTRTI, Bhubaneswar.

[50] Singh, K. S. (2012). People of India: Odisha. Anthropological Survey of India, Seagull Books, Calcuttas. 